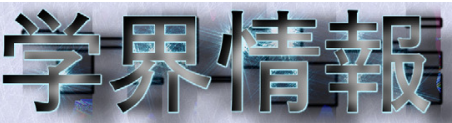

\section{International Symposium on Electrical Insulating Materials (ISEIM2011) 開催報告}

ISEIM2011（誘電体・絶縁材料に関する国際会議，2011

International Symposium on Electrical Insulating Materials）が，2011 年 9 月 6 日〜 10 日に京都市・同志社 大学寒梅館にて開催された。同国際会議は，誘電・絶縁材 料技術委員会で毎年開催している電気電子絶縁材料システ ムシンポジウムを国際化したもので，3〜4 年に一度の開催 であり，今回が 6 回目である。

ISEIM2011 では, Inuishi Memorial Lecture として Massachusetts Institute of Technology の Prof. Markus Zahn による "Unipolar Charge Transport in OilPressboard Systems with Planar, Coaxial Cylindrical and Concentric Spherical Electrode Geometries"(図 1), およびSymposium Invited Lecture として Delft University of Technology の Dr. P.H.F. Morshuis による "Defects and Interfaces at DC Voltage”の 2 件の講演をスタートに，計 128 件の発表（うちオーラル 60 件，ポスター 68 件）がなさ れた。図 2 にテーマ別の論文発表件数を示す。論文発表の うち, ポスターセッションの一部を MVP セッション (Mutual Visiting type Poster Session) および SS セッショ ン (Sun-Shine セッション) とした。これらは, ISEIM2008 にて初めて実施され, その後電気電子絶縁材料システムシ ンポジウムで毎回実施し, 本 ISEIM2011 で 4 回目の開催と なる。MVPセッションでは，ポスターセッション発表者が 同一セッション内のポスターを議論するための時間を設け るとともに，学生をはじめとする若手研究者の発表能力・ ディスカッション能力の向上を目的としたものであり，5〜 7 名の発表者で 1 グループを構成し, グループ内で相互に各 自のポスターを紹介し，質疑応答を受けるセッションであ る。コーディネータとして大学の先生等を各グループに 1 名配し，質疑応答の活発化を図ることも行っている。この 状況を図 3 に示すが，中には規定の時間を超えて議論が盛 り上がったところもあり，相当の効果が得られたものと考 えている。また，SSセッションは，関連分野の企業等の研 究者に各社・組織の研究開発動向をポスター形式で紹介し て頂き，あわせて各種サンプルや測定器の実物のデモも可 能としたものである。企業の最新の動向に学生等若手研究 者のみならず, 大学のベテランの先生方も大変興味を持っ てご参加頂いたようであった。

（株）島津製作所等を見学するテクニカルツアー，舞妓芸 で日本文化に親しんで頂いたバンケットなどを通して，参 加者は相互に親交を深め，更なる研究の発展を期したもの と期待される。最終的に，本国際会議には，表 1 に示すよ うに，15の国と地域から 141 名の参加を得て, 盛況のうち に終了することができた。参加頂いた各位，開催にあたっ

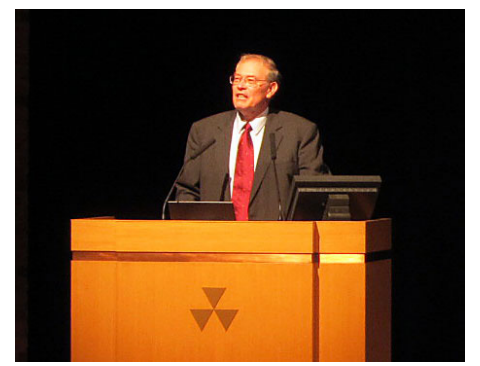

図 1 MIT・Prof. Zahn による Inuishi Memorial Lecture

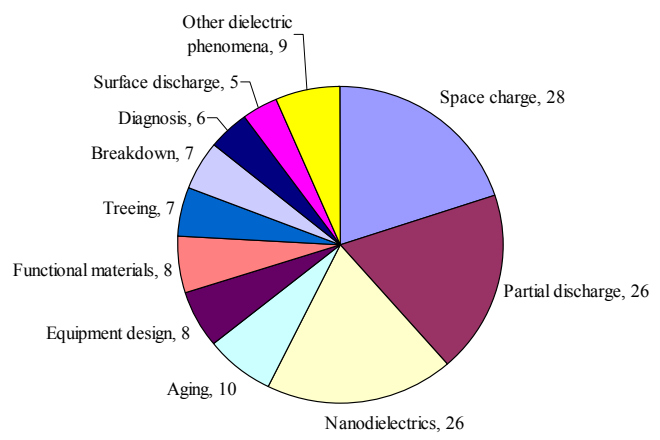

図 2 テーマ別論文数

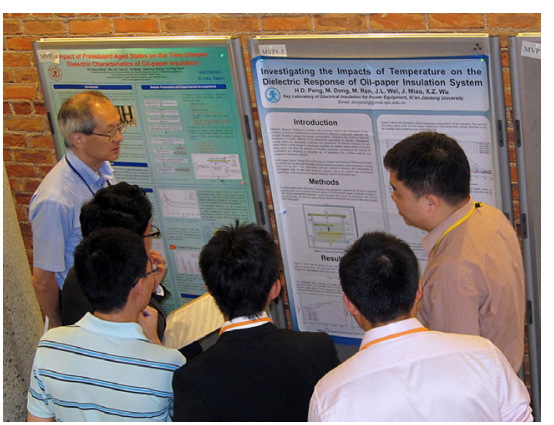

図 3 MVP セッションの状況

表 1 参加者の国・地域別統計

\begin{tabular}{|l|r|l|r|}
\hline Australia & 1 & India & 1 \\
\hline China & 32 & Netherlands & 1 \\
\hline France & 1 & Poland & 2 \\
\hline Hong Kong & 1 & Sweden & 1 \\
\hline Italy & 2 & U.S.A. & 1 \\
\hline Japan & 92 & Thailand & 1 \\
\hline Korea & 1 & United Kingdom & 2 \\
\hline Indonesia & 2 & Total & 141 \\
\hline
\end{tabular}

てご協力頂いた各位に深謝する。閉会にあたって，次回は 2014 年に開催されることがアナウンスされた。各位の積極 的な参加を望むところである。

高橋 俊裕・布施 則一〔(財)電力中央研究所 (2011 年 11 月 1 日受付) 